\title{
ENHANCING KNOWLEDGE OF BULLYING BEHAVIOR THROUGH CREATIVE PEDAGOGY AMONG STUDENTS
}

\author{
${ }^{1}$ Jamalsafri Saibon, ${ }^{2}$ Amelia Leong Chiew Har \& \\ ${ }^{3}$ Muhamad Zahir Abd. Razak \\ School Educational Studies \\ Universiti Sains Malaysia, Malaysia
}

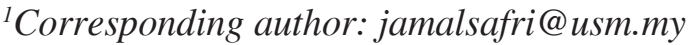

\begin{abstract}
Purpose - Bullying is one of the most worrying issues among teachers, parents, and students. Hence, prevention action should be taken to prevent bullying at school. Therefore, the Program 2BS: I'm a Buddy not a Bully, has been implemented with an aim to enhance knowledge on bullying among students. This paper examines the effectiveness of pedagogical creative approaches to increase bullying knowledge and awareness among students. Creative and fun pedagogy have been used as an approach to achieve the objectives of this program.

Methodology - A total of 234 students from different school orientations and aged 14-16 years participated in this experimental research. This study employs a quantitative method with the support of qualitative approaches utilizing quasi experiments design. An interview was conducted with seven students to obtain a deeper understanding of the effectiveness of creative pedagogy.
\end{abstract}

Findings - The results showed a significant increase in knowledge of bullying behavior among students who had participated in this program. The findings from the interviews show that by using this creative pedagogy approach, students were more excited and could understand the content better.

Significance - The findings are significant to teachers and learners, because they can act accordingly towards bullying behavior. This program provides an alternative to implementing bullying 
prevention programs that are oriented towards enhancing knowledge on bullying among students.

Keywords: Creative and Fun Pedagogy, bullying behavior, knowledge and awareness of bullying behavior, 2BS program.

\section{INTRODUCTION}

The issue of bullying among schoolchildren is a global phenomenon that has seriously increased in the recent years. According to Shakooret. al. (2012), bullying has became a major concern in many parts of the world as school children are bullied. Naturally, bullying prevention and anti-bullying program are needed to prevent it from becoming more serious. In addition, Uba, Yaacob, Juhari, and Talib (2010) emphasized that bullying has not just caused harm to other students but also has reached to a dangerous level i.e. costing lives. This suggests that bullying behavior among students in school should not be taken lightly or regarded as school culture, and immediate action should be taken to prevent bullying behavior from spreading and becoming uncontrollable.

There are many factors that contribute to the occurrence of bullying behavior such as family dynamics (Hazler, 1996), parenting and family environment (Keenan, Evans \& Crowley, 2016); styles and characteristics of the family's parenting (Cummings, Davies, \& Campbell, 2000); peer social status (Jamalsafri, 2015); role models (Olweus et al., 2007); school, teacher, and class size (Rigby \& Smith, 2011R); school environment (Astor, Meyer and Behre, 1999); the use of technology, media images, and messages (Cherney and London 2006); and also violent television shows and computer games (Anderson \& Bushman, 2001). Most previous researchers focused on factors related to family, school, peer group, and the influence of mass media and technology as the cause of bullying behavior. However, studies related to the factors of bullying behavior among students are scarce and few researchers have studied this phenomenon.

Jamalsafri (2012) indicated that though there is a lack of knowledge regarding bullying behavior among students, there is a correlation between the level of knowledge on bullying behavior and the level 
of bullying among students. This finding suggests that a student with less knowledge about bullying behavior tends to behave as a bully. This situation, if not prevented, may lead to more alarming bullying incidents in the future. Therefore, there should be bullying prevention programs in school that emphasize knowledge and awareness of bullying behaviors.

There are several bullying prevention programs that have been implemented in several European countries. Olweus Bullying Prevention Program (OBPP), a leading prevention program, is one example. The main goals of OBPP are to reduce the existing bullying problems among students, to prevent the development of new bullying problems, and to achieve better peer relations (Olweus et al., 2007). There are many bullying prevention programs that have been developed and implemented with various approaches but not many are related to bullying prevention programs that emphasize knowledge and awareness of bullying behaviors among students.

The researchers of this paper have experimented with "The 2Bs Program: I'm a Buddy not a Bully" (from here onwards will be referred to as 'the program'), which is a bullying prevention program that emphasizes knowledge and awareness of bullying among students. The pilot study of this program was conducted in several schools in the northern states of Malaysia. This program applied a creative pedagogy approach to increase knowledge and awareness on bullying among students. This creative pedagogical approach is the core of this program, which disseminates bullying behavior knowledge. This approach has been applied in each station through interactive activities between students and the facilitator. The elements of creative pedagogy that have been applied to each station are music, sculpture, poetry, acting, dance, paper collage, small game, interactive quizzes, and puppet shows with a bullying theme. This approach is in line with the target group for this program i.e. students who are in their teens and enjoy interactive activities. As such, it is necessary to examine to what extent a creative pedagogical approach may increase knowledge about bullying behavior.

This study was designed to investigate whether a creative pedagogy approach, which is applied in the program, can enhance the knowledge of bullying behavior among students. This study also examined whether through the knowledge gained from this program, 
student awareness of bullying behavior could be indirectly enhanced. The study identifies more in-depth information of the features for a creative pedagogical approach that influences its effectiveness using interviews.

The research questions based on the objectives of this study are as follows.

1. Is there a significant difference, the score of knowledge about bullying between pretest and posttest for students who are following the program using a pedagogical creative approach?

2. How a creative pedagogical approach can improve knowledge about the bullying of students who participate in the program?

The hypotheses of the study based on the objectives of this study are as follows.

1. There is no significant difference for the score of knowledge about bullying between pretest and posttest for students who are following the program using a pedagogical creative approach?

\section{LITERATURE REVIEW \& THEORETICAL PRESPECTIVES}

Although bullying is known to be a serious and worrying issue in schools, it has not been given the appropriate attention and emphasis by teachers, students, and parents (Shakoor et. al., 2012). Most of the bullying prevention programs practice and implemented only educate teachers and students on the actions to be taken to stop bullying in school but few to none educate students to recognize and distinguish the act of bullying (Pepler, Smith, \& Rigby, 2004). Hence, actions are only taken after bullying has happened (Furlong $\&$ Morrison, 2000), because they are unable to prevent it as they do not know how to recognize bullying behavior.

To be equipped with the knowledge of bullying is to know the meaning of bullying, the types of bullying, and to recognize the act of bullying. In addition, students should also be educated on how to stand up against bullying as a victim and as a bystander. It should 
be instilled in all students that bullying should never be tolerated and should be reported to school authorities. On the other hand, it is ideal to inform teachers on the importance of educating students on bullying by teaching them to identify and recognize it as well as to stand up to bullies and report any bullying to school authorities. However, teachers are believed to be 'powerful' in stopping bullying if teachers acted towards cases reported by students (Lindenberg, 2013).

To date, bullying prevention programs and mobile applications such as KnowBullying, STOP!, Bully Button, My Mobile Watch Dog, Net Nanny, BullyTag, and Anonymous Alerts only serve as platforms for parents to monitor their children and for students to report on bullying when there is one. None of these educate students to recognize bullying, the types of bullying, and on what to do when encountering bullying as a victim or a bystander. There are various of programs on alerting and reporting bullying but programs on educating students (Wilson, Lipsey \& Derzon, 2003; Wilson $\&$ Lipsey, 2007) remain scarce. The program was designed and implemented to create awareness and knowledge among students, teachers, and parents to prevent it from happening in an educational setting.

\section{Knowledge on Bullying Behavior}

As bullying is not a new phenomenon and is a worrying issue among teachers and students, it is crucial to educate and equip both alike with knowledge on bullying behavior (Yaakub, Haron \& Goh, 2010). A student with high levels of knowledge about bullying behavior should know and understand well bullying terms, concepts, characters, types of behavior, ways to deal, how to avoid it, how to help victims, and the factors causing this behavior.

Bullying behavior refers to a situation where powerful individual or group of people, repeatedly and intentionally cause injury or danger to people or groups of people who are helpless to respond (Rigby, 2000). Bullying may persist from time to time and is often hidden from the adults and persists if no action is taken. Bullying is also known as a behavioral related problem that impacts the lives of many family members especially their children (Cummings, Davies \& Campbell, 2000). Children who are bullied usually experience 
fear, humiliation, and frustration that consequently causes low selfesteem, isolating themselves from their peers, absences from school, and changes in personality, mood swings, depression, and suicidal thoughts (Suckling \& Temple, 2002).

Children and adults alike may experience many different types of bullying. While some of them are obvious and easily identified, others are subtler. There are many types of bullying: physical bullying, verbal bullying, social bullying, and cyber bullying. Physical bullying includes hitting, kicking, tripping, pinching, and pushing or damaging property. Physical bullying causes both short-term and long-term psychological damage; for instance, it is believed that long-term, victims may suffer from mental health problems after being bullied (McDougall \& Vaillancourt, 2015). The long-term consequences include not sleeping well, a tendency to wet the bed, feeling sad, depression, low self-esteem, anxiety, and suicidal thoughts (Shellard, 2002). Findings from research showed that male school children are more involved, more aggressive, and directly involved in bullying. They have a higher tendency for bullying a victim physically when compared to female school children (Scheithauer et. al., 2006). Card, Stucky, Salawani, and Little (2008) also indicated that regardless of age, ethnicity, social class, or culture or nationality that males are more likely to engage in physical bullying when compared to females. Verbal bullying includes name calling, insults, teasing, intimidation, homophobic or racist remarks, or verbal abuse. While verbal bullying can start off harmless, it can escalate to levels that start affecting the individual target.

Social bullying, sometimes being referred as covert bullying, is often harder to recognize and can be carried out in the absence of the victim. It is designed to harm someone's social reputation and/ or cause humiliation. The victims would normally possess low self-esteem, feeling oneself not good enough, or depression when they face exclusion bullying (Boulton, Trueman, \& Murray, 2008). Cyber bullying can be overt or covert bullying behaviors using digital technologies, including hardware such as computers and smartphones, and software such as social media, instant messaging, texts, websites, and other online platforms. It can happen at any time, in public or in private and sometimes only known to the target and the person bullying. 
The knowledge of bullying behavior benefits many students when they face bullying situations in school. It helps them to take the appropriate actions such as standing up against the bully or reporting the bullying to the teachers when they encounter one. Students would also learn that bullying is not right and will not be tolerated. As such, it is anticipated that students with high level of bullying behavior tend to not bully other students.

The program is believed to be able to create awareness and knowledge on bullying among students and teachers. To implement the program, a creative and fun pedagogy was put into the practice. This pedagogy was introduced by Andrei Aleinikov (1989) with the main idea for teachers to transform their classrooms into creative learning environments. If pedagogy is defined as the study of the process of teaching, then creative pedagogy is defined as the science and art of creative teaching (Aleinikov, 1990). Creative pedagogy is a branch of pedagogy that emphasizes the leading role of creativity for successful learning. At its essence, creative pedagogy teaches learners to learn creatively, become creators of themselves, as well as the creators of their futures.

There are various definitions related to creative pedagogy. Creative pedagogy involves teachers making learning more interesting and effective by using imaginative approaches in the classroom (Cremin, Burnard, \& Craft, 2006). To implement creative pedagogy, teachers need to widen their understanding of their own creativity, imaginative approaches, and repertoire of engaging activities that they can employ in developing the capacity for original ideas and actions.

Creativity requires new ways of thinking, acceptance of uncertainties, and a willingness to accept failure. It is important to provide a conducive environment that will provide students with courage by learning new experiences. For example, if the students feel valued, their confidence and independence levels will increase. Thus, they will begin to take responsibility for their own learning. Teacher and student relationships are important in contributing for this to develop. Teachers play an important role as facilitators to encourage active and flexible participation from students and make the teaching process a creative learning process (Dineen \& Niu, 2008). Creative pedagogy promotes student-centered learning as it provides learners 
with full control and responsibility towards their own learning. Learners engage actively in the learning process by being able to enquire, discuss, and argue actively on the topics learned.

Creative pedagogy is closely linked to behaviorist theory and humanistic theory. Behaviorist theory in creative pedagogy often discusses external factors that influence learner behaviors and personalities. Behaviorist theory highlights learner behavior and learning outcomes after exposure to creative learning. This theory also stresses learning outcomes regardless if they are positive or negative. Behaviorist theory discusses learning being determined by the teaching approach. For instance, exposure to games (a platform for implicit learning) in learning enables learners to learn better as learning through games enables learning to be conducted in a less stressful, creative, and fun environment. In addition, learning through songs and movies enables positive learning outcomes from learners where learning is achievable and effective. In creative pedagogy, the stimuli or the external factor that influences learning outcomes is creative pedagogy. The learning outcomes are the result from the use of creative pedagogy.

Humanistic theory underlies creative pedagogy. Humanistic theory discusses the motivations for human development. This theory proposes that creativity in learning enables human to experience a higher value from their lives. Hence, humanistic theory is relatable to the use of creative pedagogy in an education system. In terms of using creative pedagogy for teaching and learning purposes, creative pedagogy used for teaching purposes serves as motivation. The more creative the teaching approach, the better the learning outcomes. The use of creative pedagogy in an education setting is expected to be able to achieve positive learning outcomes.

Dineen and Niu (2008) indicated that creative pedagogical models can enhance creativity, levels of confidence, and intrinsic motivations. The classroom needs to transform into a flexible learning environment. The four components of creative pedagogy are as follows:

1. Fluency-generating new ideas;

2. Flexibility-shifting perspectives;

3. Originality-doing something new;

4. Elaboration-building on existing ideas. 
The table below shows how the four core components of creative pedagogy were used in the development of the program. The program represents the two words that start with the letter B, namely, bully and buddy. This program has been planned and implemented based on research that found the levels of knowledge on bullying among students was at a low level. This study also found that there is a negative significant correlation between the levels of knowledge on bullying and the level of bullying.

Thus, in 2010, the program: 'I'm a Buddy, not a Bully' was designed and developed to enhance knowledge on bullying behavior and to nurture awareness among school students. The program is funded by the Division of Industry and Community Network, University Sains Malaysia (USM), and The School of Educational Studies, USM which has extended their support throughout this program. The State Educational Department of Penang, the schools and the respondents of the survey also gave their unwavering support.

The program was implemented in three major phases. The first phase of the program aims to enhance knowledge and to create awareness of bullying problems among students through creative pedagogy approaches and the execution of the 'I'm a Buddy, Not a Bully' campaign. The concepts underlying the first phase involve the extensive use of creative and fun pedagogical approach, which was introduced by Dr. Andrei Aleinikov.

The first phase uses a system of four stations that has its own specific theme related to bullying: 'My Best Friend', 'Be Part of the Solution', 'What's in my Mind?', and 'Hati Buddy'. This approach will equip the target groups with the knowledge, awareness, and actions to be taken when dealing with bullying situations. The creative and fun pedagogical approach includes utilizing elements of art such as music, sculpting, poetry, acting, dancing, paper collaging, and puppetry with a bullying theme. This was presented and guided by facilitators, counselors, and teachers who had undergone training.

The creative pedagogy framework was used to develop the program. Table 1 shows the four components that reflect the elements of creativity in learning that are crucial in identifying the key activities of the program. These four components could be cyclical as well as sequential. One may begin at any juncture or consider any of the four element as the beginning element. 


\section{Table 1}

\section{The Core Components of creative pedagogy in the Program 2Bs}

\begin{tabular}{|c|c|c|c|}
\hline Elements & Program 2Bs & Students & Note \\
\hline $\begin{array}{l}\text { 1. FLUENCY } \\
\text { (generating new } \\
\text { ideas) }\end{array}$ & $\begin{array}{l}\text { Title: My Best } \\
\text { Friend } \\
\text { Introduces the } \\
\text { concept of buddies } \\
\text { as the solution } \\
\text { to the bullying } \\
\text { problem. }\end{array}$ & $\begin{array}{l}\text { The creative pedagogy } \\
\text { utilizes sculpture perfor- } \\
\text { mance, storytelling and } \\
\text { rhyme and dance in in- } \\
\text { troducing the concept of } \\
\text { buddies to the learners. }\end{array}$ & $\begin{array}{l}\text { Students are } \\
\text { introduced and } \\
\text { emphasized on } \\
\text { the concept of } \\
\text { friendship and } \\
\text { trusting their } \\
\text { friends in helping } \\
\text { them to overcome } \\
\text { bullying. Friends } \\
\text { are buddies whom } \\
\text { the students } \\
\text { can lean on in } \\
\text { overcoming } \\
\text { bullying. }\end{array}$ \\
\hline $\begin{array}{l}\text { 2. FLEXIBIL- } \\
\text { ITY } \\
\text { (shifting per- } \\
\text { spectives) }\end{array}$ & $\begin{array}{l}\text { Title: Be Part of } \\
\text { the Solution } \\
\text { The roles and } \\
\text { characters of the } \\
\text { Bully, Victim and } \\
\text { Bystander are be- } \\
\text { ing discussed. }\end{array}$ & $\begin{array}{l}\text { This component utilizes } \\
\text { mannequin/puppet act, } \\
\text { dialogue and spontane- } \\
\text { ous role-play based } \\
\text { on different situations } \\
\text { to help the students to } \\
\text { comprehend the situation } \\
\text { of each character. }\end{array}$ & $\begin{array}{l}\text { Students are given } \\
\text { the chance to play } \\
\text { different roles - } \\
\text { the Bully, Victim } \\
\text { and Bystander, } \\
\text { to experience } \\
\text { the unpleasant } \\
\text { experience and } \\
\text { trained to solve } \\
\text { the bullying } \\
\text { wisely. }\end{array}$ \\
\hline $\begin{array}{l}\text { 3. ORIGINAL- } \\
\text { ITY } \\
\text { (doing some- } \\
\text { thing new) }\end{array}$ & $\begin{array}{l}\text { Title: What is in } \\
\text { my Mind? } \\
\text { To show and } \\
\text { understand the } \\
\text { feelings of a } \\
\text { Bully, Victim, and } \\
\text { Bystander and the } \\
\text { actions needed } \\
\text { to be taken when } \\
\text { dealing with bul- } \\
\text { lying }\end{array}$ & $\begin{array}{l}\text { This component utilizes } \\
\text { videos, coloring, match- } \\
\text { ing and making paper } \\
\text { collage activities to } \\
\text { express their feelings } \\
\text { and opinions playing } \\
\text { each character. }\end{array}$ & $\begin{array}{l}\text { The students } \\
\text { are given the } \\
\text { opportunity to } \\
\text { discuss and reflect } \\
\text { the meaning of } \\
\text { bullying in actual } \\
\text { situations }\end{array}$ \\
\hline $\begin{array}{l}\text { 4. ELABORA- } \\
\text { TION } \\
\text { (building on } \\
\text { existing ideas) }\end{array}$ & $\begin{array}{l}\text { Title: Hati Buddy } \\
\text { To reflect on the } \\
\text { activities, they } \\
\text { have done before } \\
\text { this }\end{array}$ & $\begin{array}{l}\text { This component utilizes } \\
\text { game mode approach to } \\
\text { reflect in thorough what } \\
\text { they have been exposed } \\
\text { to. }\end{array}$ & $\begin{array}{l}\text { The effects of } \\
\text { bullying behavior } \\
\text { on the emotional, } \\
\text { social and intel- } \\
\text { lectual sides of } \\
\text { the victim and } \\
\text { the bully were } \\
\text { discussed. }\end{array}$ \\
\hline
\end{tabular}


Based on the table above, the four components of creative pedagogy used in developing the program. Each component was used in implementing each stage of the program. Unlike the conventional way of delivering inputs by using chalk-and-talk, fun and practical applications were utilized in educating students about bullying. The program developed by creative pedagogy utilizes storytelling, dancing, role-play, coloring, videos, and games to deliver inputs.

First and foremost, 'Fluency' aids the first stage of the program to introduce the concept of buddies as a solution in overcoming bullying by utilizing sculpture, performance, storytelling, rhymes, and dance to introduce the concept of buddies. Instead of just telling the students that friends can help them to overcome bullying behavior, creative pedagogy enables an ability to portray through practical application of friendships via storytelling, sculpture, performance, and dance as these activities require teamwork and cooperation. Indirectly, learners are exposed to the importance of having friends, respecting each other, and helping each other to achieve a mutual goal such as overcoming bullying.

Next, the learners proceed to the second activity where they are given the opportunity to take turns to play the role of the Bully, Victim, and Bystander in a bullying incident. This stage is known as 'Flexibility'. This stage provides the students with authentic experience and feelings of the roles in a bullying incident. Roleplay enables the students to be 'in-the-shoes' and empathize with the feelings of $t$ roles. Thus, this aims to educate students on the appropriate actions to be taken if they were the bully, victim, or bystander. For instance, it is hoped that those with a high tendency to bully other students will stop bullying as they will experience the unpleasant experience of being bullied.

Moreover, creative pedagogy provides an opportunity to discuss and reflect on different roles and comprehend the actual meaning of bullying in the third stage of the program. 'Originality' is one of the four core components. Instead of just verbally expressing their thoughts and feelings as usual, the learners are required to do some coloring, make collages, and watch videos to express their feelings towards bullying and the characters involved in bullying. This approach is useful for those students who are passive or afraid in voicing themselves. Their opinions can be heard through these activities. 
Finally, a game was put into use in the 'Hati Buddy' stage of the program. This game tested $t$ on the overall knowledge and sought learner comprehension as well as the emotional, social, and intellectual effects on victims and bullies. 'Hati Buddy' can examine student knowledge on bullying and student opinions on the effects of bullying in a stress-free and fun way. Learner anxiety filters was lowered and learners will be able to get better at the game.

The creative pedagogy approach used in developing the program was able to attract interest and the attention of the students to learn, comprehend, and to handle bullying situations. It is believed that this approach is effective in increasing student awareness and knowledge of bullying behaviors according to both behaviorist theory and humanistic theory. It is believed that positive learning outcomes (learner comprehension of the knowledge on bullying) can be achieved through stimuli and motivation (dancing, sculpture performance, coloring, role-play, puppet act, collages, and games) given in the learning process.

\section{METHODOLOGY}

This study employs a quantitative method with the support of qualitative approaches. Quasi experiment design, which randomly assigns whole classes to treatment and control (Campbell \& Stanley, 1963), was used to examine the effectiveness of pedagogical creative approaches in increasing bullying knowledge and awareness. Meanwhile, interviews were also conducted on five students to obtain a deeper understanding of effectiveness. A total of 234 pupils were randomly selected as samples from five different oriented schools in the state of Penang, Malaysia. The sample consists of 130 male students and 104 female students aged $14-16$ years. The lottery method is a random sampling that has been used to select samples. Meanwhile, the schools were proposed by the Penang State Education Department, which consisted of two secondary schools, one religious school, one high-performing school, and one sports school.

In this quasi experiment, students have undergone pre- and posttests. The Student Bullying Knowledge Level (TPBL) questionnaire was adapted from Jamalsafri (2010) and administered to the samples 
before and after the program was implemented. This questionnaire contains 25 items that examine student knowledge about bullying behaviors. The TPBL questionnaire contains a number of dimensions to measure the level of knowledge of bullying among students. The dimensions consist of the terms of definitions, concepts, characters, types of behavior, ways to deal with bullies, how to help victims, and the factors causing bullying behaviors. The questionnaire has undergone validity and reliability processes conducted before the study. The TTLB questionnaire has been tested for validity by referring local experts regarding bullying behavior. The reliability process of the TTLB questionnaire was carried out involving 44 students and obtained a Cronbach's Alpha of 0.82 .

Structured interviews were conducted on seven randomly chosen students who had participated in the program. A total of 4 boys and 3 girls were selected for each school based on the number draw. The aim of the interviews was to obtain student feedback regarding the effectiveness of the creative pedagogy approach in increasing their knowledge of bullying. Protocol interviews emphasized positive elements of creative pedagogy that had an impact on improving knowledge about bullying among students. Among the items questioned on the subject were 'Did you feel that this program has increased your knowledge about bullying? If 'Yes', what are the features of this program that help improve your knowledge about bullying behavior?

Before undergoing the program, the samples responded to the TPBL questionnaire. This measured students' existing knowledge about bullying behaviors before they joined the program. After the program, they were asked to answer the questionnaire once again. TTLB questionnaires were analyzed using SPSS version 23.0. To measure the effectiveness of the creative pedagogical approach in enhancing the knowledge among students, a T-test analysis was performed to obtain statistical data. Meanwhile, the analysis interviews used the six steps prescribed by Braun and Clarke (2006) to carry out thematic analysis. Through thematic analysis, some procedures were conducted such as familiarization with the data, generating initial codes, searching for themes, reviewing themes, defining and naming themes, and producing the report. 


\section{RESULTS}

This study was designed to test a hypothesis: there is a significant difference between pre-test scores and post-test scores on bullying behavior knowledge among students who have participated in the program. Findings from the pre-test questionnaires (Table 2) showed that the mean score of the students on knowledge and awareness of bullying is at a moderate level (Mean $=49.66$ ). After undergoing the program, the student mean score of the post-tests questionnaires increased to a moderate high level (Mean $=72.77$ ). This indicates that there has been a significant increase in student scores on their knowledge on bullying behavior between the pretest and post-test.

Table 2

Paired Samples Statistics

\begin{tabular}{cccccc}
\hline & Mean & N & Std. Deviation & Std. Error Mean \\
\hline \multirow{2}{*}{ Pair 1 } & Test1 & 49.66 & 234 & 13.57 & 1.249 \\
\cline { 2 - 6 } & Test 2 & 72.77 & 234 & 9.73 & .896 \\
\hline
\end{tabular}

This finding shows that creative pedagogy applied in the program has managed to improve achievement scores. Analysis from Paired Samples Correlations showed (Table 3) that there is a significant correlation between the pre-test and the posttest $(\mathrm{p}<.001)$. These findings indicated that the enhancement of knowledge and awareness on bullying that involved all the participants in the study.

Table 2

Paired Samples Correlations

\begin{tabular}{lr|ccc}
\hline & & $\mathrm{N}$ & Correlation & Sig. \\
\hline Pair 1 & Test1 \& Test 2 & 234 & .567 & .000 \\
\hline
\end{tabular}

Experimental methods were used to evaluate the effectiveness of the program. The results of the T-test below showed that there is a significant difference $(t=-22.106, d f=233, p>.01)$. The test 
results showed that the program has influenced the performance of students to answer the questions related to knowledge of bullying and awareness on diversity among peers. The difference in the mean score value for both the tests is large. These findings indicate that the creative pedagogy approach used in the program managed to increase knowledge and awareness of bullying among students who live at the school hostel.

Table 3

Paired Samples Test

\begin{tabular}{|c|c|c|c|c|c|c|c|c|}
\hline & \multicolumn{5}{|c|}{ Paired Differences } & \multirow[b]{3}{*}{$\mathrm{t}$} & \multirow[b]{3}{*}{$\mathrm{df}$} & \multirow[b]{3}{*}{$\begin{array}{c}\text { Sig. } \\
\text { (2-tailed) }\end{array}$} \\
\hline & \multirow[t]{2}{*}{ Mean } & \multirow[t]{2}{*}{$\begin{array}{c}\text { Std. } \\
\text { Deviation }\end{array}$} & \multirow[t]{2}{*}{$\begin{array}{l}\text { Std. } \\
\text { Error } \\
\text { Mean }\end{array}$} & \multicolumn{2}{|c|}{$\begin{array}{c}95 \% \\
\text { Confidence } \\
\text { Interval of the } \\
\text { Difference }\end{array}$} & & & \\
\hline & & & & Lower & Upper & & & \\
\hline $\begin{array}{l}\text { Pair } 1 \\
\text { Test1 - } \\
\text { Test } 2\end{array}$ & -23.11 & 11.36 & 1.04 & -25.18 & -21.04 & -22.10 & 233 & .000 \\
\hline
\end{tabular}

Thematic analysis of the data has produced six themes i.e. fun, simulated, indirect learning, spontaneous, raising awareness, and brainstorming. The interview findings also found that students were excited to be involved in the program and they applied the creative approach as required by the program, where possible adn feasible. Fun and simulated experiences through the planned creative activities have given them an understanding and real-world picture of bullying behavior. In the conversation below, a teacher explains that creative pedagogy approach can increase the knowledge of bullying to students.

Researcher: 'Did you feel that this program has increased your knowledge about bullying?

If 'Yes', what are the features of this program that help improve your knowledge about bullying behavior?

Student C: Yes. 
Students C: The activity of this program is very good ... not boring as the usual briefing is held ... just listen only ... bored... but the program is very exciting /

Student E: $\quad$ Yes, helps me a lot to understand ... there's a simulation ... acting as a bully and a bully victim ... we think, what they feel ... is fun and easy to understand ... /

This finding suggests that the theme of fun activities helped to improve students' knowledge about bullying behaviors. This is because programs related to discipline are usually conducted as lectures and in formal situations. This contrasts with the way the program is implemented, which is relaxing, and encourages the students to explore fun and creative elements, and simultaneously acquire knowledge on bullying behaviors.

In addition, they can also feel and gauge the experiences of the bully, the victim, and the bystander experience through role-plays, acting and expressions of feelings. This indirectly raises students' awareness of how serious the effects of bullying behaviors are. This is seen as reinforcing their knowledge of bullying behavior that is taking place. It also suggests that creative pedagogy activities train them to closely examine the issues of bullying from diverse perspectives and thus, better understand bullying behavior.

$\begin{array}{ll}\text { Student F: } & \text { I like station } 2 . . . \text { we have the chance to } \\ & \text { be a bully and a victim ... we will feel } \\ & \text { what they feel ... even acting but like } \\ & \text { real ... raises consciousness to me .../ } \\ & \text { Station } 1 \text { made me aware of the meaning } \\ & \text { of friendship ..., when we sharing about } \\ & \text { our best friend, made me sad ..., before } \\ \text { Student } & \text { this, I thought my friends were not } \\ & \text { important .../ }\end{array}$

The study also suggests the theme of sharing ideas and activities spontaneously, which has this creative pedagogical approach that successfully helped to improve students' knowledge about bullying behavior. Brainstorming activities in station three have provided 
information on contributing factors to bullying behavior. In addition, students also contribute ideas on how to solve bullying issues.

\begin{tabular}{|c|c|}
\hline Student A: & $\begin{array}{l}\text { All the activities in each station are fun... } \\
\text { I love the 'Tribunal Bully' station... we } \\
\text { can generate ideas... share information } \\
\text { how to deal with bully in exciting } \\
\text { activities.../ }\end{array}$ \\
\hline
\end{tabular}

Student G: Very good way of delivering... easy to understand cause of bullying case... spontaneously.../

Overall, this quasi experimental study has shown that the pedagogical creative approach applied in the program has helped to increase awareness for students about bullying behaviors.

\section{DISCUSSION}

The findings of the study have shown that the creative pedagogical approach is effective in improving students' knowledge about bullying behavior, which can be explained by behaviorist theory and humanistic theory. This is evidenced by post-test scores on knowledge about bullying that significantly increased when they underwent treatment in the program, which applied a creative pedagogical approach. According to behaviorist theory, the creative pedagogy used in teaching acts as stimuli or external factors that affect learning. Learning outcome is dependent on the creative pedagogy used in the teaching and learning process. This is similar with those highlighted by humanistic theory. The humanistic theory explained positive learning outcomes are the result of a positive teaching approach (motivation). When positive learning outcomes were achieved through the usage of creative pedagogy, it suggests that creative pedagogical approaches are appropriate for delivering learning content. This finding also supports Sivan et al (1991) by showcasing better learning outcomes and enhancing learning (Benjelloun, 2009), producing more effective learning (Robinson, \& Kakela, 2006) able to increase curiosity to the learners (Lin, 2011), and students will achieve better results (Toivanen, Halkilahti, \& Ruismäki, 2013). 
This may be due to the characteristics of learning through a creative pedagogical approach, which led to a significant increase of student knowledge about bullying behavior. As posited by humanistic theory, the creative factor used in certain circumstances has the capacity and capability to improve student development. Also, the positive learning elements contained in the creative pedagogy approach used in this study become the catalyst for a significant increase in students' knowledge about bullying behavior and, indirectly, through the acquired knowledge.

Creative pedagogy has demonstrated that creative activities will make the students become more aware of the seriousness of bullying and the negative implications of such acts. In schools, bullying cases that occur normally are often approached using punishments that will negatively affect the bully and the use of lame strategies that do not address completely solve the problems. For example, as stated by a student who was interviewed, most bullying prevention programs are often carried out in the form of tedious lectures. On the contrary, the creative pedagogical approach applied in this program has provided an alternative and far more better solution by enhancing the student's knowledge and awareness on bullying among students.

\section{CONCLUSION}

The creative pedagogy approach has successfully enhanced students' knowledge and awareness of bullying among students based on the significant increase in the students' post-test scores on knowledge related to bullying. As explained by the behaviorism theory and the humanistic theory, the creative pedagogy, which acts as the stimuli and motivation (positive teaching approach) used in the program, determined the positive learning outcomes of the students. The use of this approach should be considered when planning and implementing a bullying prevention program as it involves and engages both the teachers and students actively and purposefully.

This active and purposeful involvement of the stakeholders is guided by the four components of the creative pedagogy - fluency, flexibility, originality and elaboration. These four elements integrally emphasize on the elements of fun and creativeness in the conducting the program. For instance, games, digital storytelling, 
drama, storytelling, and brainstorming can be used in applying creative pedagogy in bullying prevention program. The knowledge of bullying obtained through this approach will create students' awareness about bullying behavior and, indirectly, bullying issues and eventually prevents misconceptions about bullying behavior that causes bullying. Creative pedagogy will certainly lead to positive beahaviours among students, and Swearer et al. (2010) concur that positive peer influences or a positive school climate 'deters adolescents from engaging in bullying perpetration' (p. 43).

The current program was scientifically developed, taking into consideration various pedagogical and technical factors (based on creative and humanistic pedagogy) that would facilitate and guide teachers on how to generate ideas, creativity and to craft interesting activities that would suit needs of the students, as well as match their abilities. In addition, the program is accompanied by a complete and thorough module for teachers to refer especially in implementing the program at the school level. It is also suggested that a needs analysis is carried out to identify both teachers' and students' views and opinions on bullying. This would allow for the planners of the program to specifically identify meaningful activities that would engage the teachers and students in activities that would benefit them.

One of the main implications of this study is the need for teachers to understand, grasp and apply creative pedagogy to address bullying issues. Hence, teachers should be encouraged to apply this approach in the teaching and learning processes at school since not all teachers would have the necessary knowledge, skills and creativity to integrate content with fun activities. As such, training and courses should be given to teachers to master this creative pedagogical approach so that it can be implemented in the classroom without obstacles. Teachers' mindset of the traditional teaching and learning process using chalk and talk, one-way input delivery should be gradually transformed into accepting and incorporating creative pedagogy in teaching. The importance of implementing the four elements of creative pedagogy - fluency, flexibility, originality and elaboration in teaching should be emphasized to the teachers as this implementation encourages the generation of new ideas, different perspectives, novelty and the reification of existing ideas. Such processes would enable the teaching and learning activities to be 
more engaging, stimulating and motivating for the students. Teachers should be trained via workshops and courses on incorporating and integrating fun and creative materials, for example, customized board games, stimulations, forum style discussion and role-play into the teaching and learning process to achieve desired and positive learning outcomes.

In addition, the bullying prevention program applying creative pedagogy would pose a new dimension of learning / syllable/ curriculum to the education ministry, especially the policy and curriculum makers. This practice would enable the policy makers and curriculum makers to rethink the effectiveness of current policies and philosophies on bullying, and this may lead to partial or total reorganization and restructuring of the existing education policy and curriculum pertinent to understanding bullying issues, its related philosophies and bullying prevention programs at the national and school levels.

\section{REFERENCES}

Aleinikov AG. (1990). Creative pedagogy and creative metapedagogy. Progress in Educ, 65(12), 274-80.

Aleinikov AG. (1989). Creative metapedagogy: D-day. AlmaMater. Higher Educ Bull, 1, 34-9.

Anderson, C. A., \& Bushman, B. J. (2001). Effects of violent video games on aggressive behavior, aggressive cognition, aggressive affect, physiological arousal, and prosocial behavior: A meta-analytic review of the scientific literature. Psychological Science, 12, 353- 359.

Astor, R. A., Meyer, H. A., \& Behre, W. J. (1999). Unowned places and times: Maps and interviews about violence in high schools. American Educational Research Journal, 36, 3-42.

Benjelloun, H. (2009). An empirical investigation of the use of humour in university classrooms. Education, Business and Society: Contemporary Middle Eastern Issues, 2(4), 312-322.

Boulton M. J., Trueman M., \& Murray L. (2008). Associations between peer victimisation, fear of future victimisation and disrupted concentration on class work among junior school pupils. British Journal of Educational Psychology, 78, 473489. 
Campbell. D, T., \& Stanley. J. C. (1963). Experimental and quasiexperiment designs for research. Houghton Mifflin Company, USA.

Card NA, Stucky BD, Sawalani GM, Little TD. (2008). Direct and indirect aggression during childhood and adolescence: A meta-analytic review of gender differences, intercorrelations, and relations to maladjustment. Child Dev, 79(5),1185-229. doi: 10.1111/j.1467-8624.2008.01184.x

Cherney, I.D. \& London, K. (2006). Sex Roles, 54, 717. https:// doi.org/10.1007/s11199-006-9037-8

Craft, A. (2005). Creativity in schools: Tensions and dilemmas. London: Routledge.

Cremin, T., Burnard, P., \& Craft, A. (2006). Pedagogies of possibility thinking. International Journal of Thinking Skills and Creativity, 1(2), 108-119.

Cremin, T. (2006). Creativity, uncertainty and discomfort: teachers as writers. Cambridge Journal of Education, 36(3), 415-33.

Cummings, E.M., Davies, P.T., \& Campbell, S.B. (2000). Developmental Psychopathology and Family Process. New York: The Guilford Press.

Dineen, R., \& Niu, W. (2008). The effectiveness of western creative teaching methods in China: AnAction research project. Psychology of Aesthetics, Creativity, and the Arts, 2(1), 4252. http://dx.doi. org/10.1037/1931-3896.2.1.42

Furlong, M., \& Morrison, G. (2000). The school in school violence: Definitions and facts. Journal of Emotional and Behavioral Disorders, 8(2), 71-82.

Hazler, R.J. (1996). Breaking the cycle of violence: Interventions for bullying and victimization. Washington, DC: Accelerated Development.

Jamalsafri Saibon. (2015). The Relationship between Student's Statuses with bully behavior. Malaysian Education Deans' Council (MEDC) Journal, 5, (In Malay Language).

Joubert, M. M. (2001). The art of creative teaching: NACCCE and beyond. In Craft, A, Jeffrey,

Keenan, T., Evans, S., \& Crowley, K. (2016). An Introduction to Child Development (third edition). London: Sage.

Liebling, M (eds) Creativity in education. London: Continuum.

Lin, H. (2011). Three principles of soil change and pedogenesis in time and space. Soil Science Society of America Journal, 75(6), 2049-2070. DOI: 10.2136/sssaj2011.0130 
Lin, Y. S. (2008). Applying drama in Taiwan's primary curriculum: The reality and difficulties through primary school teachers' viewpoints. Asia-Pacific Journal for Arts Education, 6(1), 1-27.

Lindenberg, S. (2013). Social rationality, self-regulation, and well-being: The regulatory significance of needs, goals, and the self. In R. Wittek, T. A. B. Snijders, \& V. Nee (Eds.), Handbook of rational choice social research (pp. 72-112). Stanford, CA: Stanford University Press

McDougall, P., \& Vailliancourt, T. (2015). Long-term adult outcomes of peer victimization in childhood and adolescence: Pathways to adjustment and maladjustment. American Psychologist, 70, 300-310. http:// dx.doi.org/10.1037/a0039174

Olweus, D. (2007). Olweus bullying questionnaire: Schnabel paper version. Center City, MN: Hazelden.

Olweus, D., \& Limber, S. P. (2007). Olweus bullying prevention program teacher guide. Center City, MN: Hazelden

Rigby, K. (2000). Effects of peer victimisation in schools and perceived social support on adolescent well-being. Journal of Adolescence, 23(1), 57-68.

Rigby, K., \& Smith, P. K. (2011). Is school bullying really on the rise? Social Psychology of Education, 14, 441-455.

Robinson, C.F. \& Kakela, P.J. (2006). Creating a space to learn: A classroom of fun, interaction, and trust. College Teaching, 54(1), 202-206. Retrieved full-text from Wilson Web Education Full-Text, April 10, 2006.

Sania, S., Jaffee, S. R., Bowes, L., Ouellet-Morin, I., Andreou, P., Happé, F., \& Arseneault, L. (2012). A prospective longitudinal study of children's theory of mind and adolescent involvement in bullying. Journal of Child Psychology and Psychiatry, and Allied Disciplines, 53(3), 254-261. http://doi.org/10.1111/ j.1469-7610.2011.02488.x

Scheithauer, H., Hayer, T., Petermann, F., \& Jugert, G. (2006). Physical, verbal and relational forms of bullying among students from Germany: Gender-, age-differences and correlates. Aggressive Behavior, 32, 261-275.

Shakoor, S., Jaffee, S. R., Bowes, L., Quellet-Morin, I., Andreou, P., Happe, F., Moffitt, T., \& Arseneault, L. (2012). A prospective longitudinal study of children's theory of mind and adolescent involvement in bullying. Journal of Child Psychology and Psychiatry, 53(3), 254-261 
Shellard, E. (2002). Recognizing and preventing bullying. The Informed Educator Series. Arlington, VA: Educational Research Service.

Sivan, A., Leung, R. W., Gow, L., \& Kember, D. (1991). Towards more active learning in hospitality studies. International Journal of Hospitality Management, 10, 369-379.

Smith P.K., Pepler, D., \& Rigby, K. (eds.), (2004). Bullying in schools: How successful can Interventions be? Cambridge, UK: Cambridge University Press

Suckling, A., \& Temple, C. (2002). Bullying - A whole school approach. London: Kingsley Publishers Ltd.

Swearer, S. M., Espelage, D. L., Vaillancourt, T., \& Hymel, S. (2010). What can be done about school bullying? Linking research to educational practice. Educational Researcher, 39(1), 38-47.

Swearer, S. \& Hymel, S. (2015). Bullying and discrimination in schools: Exploring variations across student subgroups. School Psychology Review, 44(4), 504-509.

Tews, M. J., Jackson, K., Ramsay, C., \& Michel, J. W. (2015). Fun in the college classroom: Examining its nature and relationship with student engagement. College Teaching, 63(1), 16-26.

Toivanen, T., Halkilahti, L., \& Ruismäki, H. (2013). Creative pedagogy - Supporting children's creativity through drama. The European Journal of Social \&Behavioural Sciences, 7, 1168-1179.

Uba, I., Yaacob, S. N., Juhari, R., \& Talib, M. A. (2010). Effect of self-esteem on the relationship between depression and bullying among teenagers in Malaysia. Asian Social Science, 6(12), 77-85.

Wilson, S. J. \& Lipsey, M. W. (2007). School-based interventions for aggressive and disruptive behavior: Update of a metaanalysis. American Journal of Preventive Medicine, 33 (Supplement 2), S130 - S143.

Wilson, S. J., Lipsey, M. W. \& Derzon, J. H. (2003). The effects of school-based intervention programs on aggressive and disruptive behavior: A meta-analysis. Journal of Consulting \& Clinical Psychology, 71(1), $136-149$.

Yaakub, N. F., Haron, F., Goh, C. L. (2010). Examining the efficacy of the Olweus prevention programme in reducing bullying: the Malaysian experience. Procedia Social and Behavioral Sciences, 5, 595-598. 